\title{
Pituitary and Gonadal Effects of GnRH (Gonadotropin Releasing Hormone) Analogues in Two Peripubertal Female Rat Models
}

\author{
CHRISTIAN ROTH, FRANK HEGEMANN, JUDITH HILDEBRANDT, IVONNE BALZER, \\ ANNETTE WITT, WOLFGANG WUTTKE, AND HUBERTUS JARRY
}

Children's Hospital Medical Center, University of Bonn, 53113 Bonn, Germany [C.R.], Department of Pediatrics [F.H., J.H.], Division of Clinical and Experimental Endocrinology [I.B., A.W., W.W., H.J.], University of Göttingen, 37075 Göttingen, Germany

\begin{tabular}{|c|c|}
\hline \multicolumn{2}{|c|}{ ABSTRACT } \\
\hline $\begin{array}{l}\text { Central precocious puberty is commonly treated by gonado- } \\
\text { tropin releasing hormone }(\mathrm{GnRH}) \text { agonists. To compare modes } \\
\text { of action and effectiveness of GnRH analogues and assess treat- } \\
\text { ment combinations of agonistic (triptorelin) and antagonistic } \\
\text { (cetrorelix acetate) GnRH analogues with established treatment, } \\
\text { we used prepubertal } 31 \text {-d-old ovariectomized female rats. Stron- } \\
\text { gest inhibition of } \mathrm{LH} \text { and FSH occurred after } 2-\mathrm{d} \text { treatment with } \\
\text { antagonist alone ( } \mathrm{LH} 0.08 \pm 0.02 \text { versus } 3.2 \pm 0.56 \mathrm{ng} / \mathrm{mL} \text { in } \\
\text { controls; FSH } 10.8 \pm 2.8 \text { versus } 44.2 \pm 5.0 \mathrm{ng} / \mathrm{mL} \text { in controls, } \\
p<0.001 \text { ). Combined agonist/antagonist was second most } \\
\text { effective of the treatments (after } 5 \mathrm{~d} \text { treatment, LH } 0.52 \pm 0.15 \\
\text { versus } 4.9 \pm 1.1 \mathrm{ng} / \mathrm{mL} \text { in controls; } p<0.01 \text { ). Pituitary gonad- } \\
\text { otropin subunit LH } \beta \text { mRNA levels were inhibited in all groups } \\
\text { except controls, but pituitary GnRH receptor mRNA was stim- } \\
\text { ulated by agonist yet unaffected by combined analogues. Ex- } \\
\text { planted ovaries were incubated with either analogue, both } 10^{-6} \\
\text { M. After } 4 \text { h, GnRH receptor mRNA levels were significantly } \\
\text { reduced by antagonist but not agonist. To verify puberty- } \\
\text { inhibiting effects of GnRH analogues, we used } 26 \text {-d-old female } \\
\text { rats with androgen-induced precocious puberty after injecting }\end{array}$ & $\begin{array}{l}\text { subcutaneously single } 300 \mu \mathrm{g} \text { danazol on postnatal d 5. Single } \\
\text { application of cetrorelix depot (cetrorelix embonate) reduced } \\
\text { serum estradiol levels and pituitary LH } \beta \text { expression; GnRH } \\
\text { receptor mRNA levels were down-regulated in the pituitary and } \\
\text { ovary }(p<0.05) \text {. In androgen-induced precocious puberty } \\
\text { model, single injection of antagonist effectively arrests premature } \\
\text { hormonal activation and down-regulates pituitary and ovarian } \\
\text { GnRH receptors. We conclude that GnRH analogue combination } \\
\text { and especially antagonist alone treatment most directly suppress } \\
\text { gonadotropin levels. This implies that early treatment gonado- } \\
\text { tropin flare-up associated with agonist treatment is avoidable. } \\
\text { (Pediatr Res 55: 126-133, 2004) } \\
\text { GnRH, gonadotropin-releasing hormone } \\
\text { LH } \boldsymbol{\beta} \text {, LH subunit } \beta \\
\text { POA, preoptic area } \\
\text { MBH, mediobasal hypothalamus } \\
\text { ER, estrogen receptor } \\
\text { Co, controls }\end{array}$ \\
\hline
\end{tabular}

The episodic GnRH release from the hypothalamic GnRH pulse generator, controlled by excitatory and inhibitory neurotransmitters as well as neuropeptides and glial factors, induces the pulsatile discharge of gonadotropins from the pituitary gland, triggering a cascade of events resulting in the onset of puberty (1-6). This phenomenon has led to clinical use of GnRH agonists in treating central precocious puberty due to premature release of $\mathrm{GnRH}(7,8)$. Rather than a direct causative arresting of puberty, the pharmacodynamics of $\mathrm{GnRH}$

Received January 8, 2003; accepted June 30, 2003.

Correspondence: Christian Roth, Division of Neuroscience, Oregon Health and Science University, West Campus, 505, NW 185th Avenue, Beaverton, OR 97006 U.S.S.; e-mail: croth@ohsu.edu

Supported by the Deutsche Forschungsgemeinschaft (German Research Foundation) Grant RO 2220/2-1.

DOI: 10.1203/01.PDR.0000100463.84334.3F agonists involve an initial activation of LH and sex steroid secretion ("flare-up phase" after the first injection), followed by reduced LH levels by desensitization of pituitary GnRH receptors (9). Prolongation of the recommended application interval bears the risk of a reiterative massive reactivation of gonadotropin secretion. Treatment management is typically long-term, requiring iterative monitoring-some patients will need either higher amounts of the agonist than the recommended initial doses or shorter injection intervals. If this is noticed too late, the opposite of the aimed, inhibitory effect will be observed (10-12).

In contrast to agonists, antagonistic GnRH analogues act by competitive binding to the pituitary GnRH receptors, thereby preventing the action of endogenous GnRH (13). Theoretically, antagonists could offer an almost immediate, direct, and dosedependent alternative for treating precocious puberty. In pre- 
pubertal/peripubertal female rats, short-acting cetrorelix acetate inhibits pubertal development (14). The commercially available formulation of the antagonist cetrorelix, Cetrotide, introduced 1999, was developed as a concomitant in assisted reproduction, exerting gonadotropin inhibition of 1 to $3 \mathrm{~d}$ duration after a single s.c. injection. This short duration of action is suboptimal for the typical long-term treatment of precocious puberty, as children would need at least 10 injections per month instead of a more desirable one-injection-permonth, long-acting depot GnRH analogue.

Another consideration in the management of precocious puberty is estrogen, which plays a critical role in the growth and development of reproductive tissues, as well as in sexual differentiation and fertility. These biologic actions are exerted by the binding of estrogen to ER (15). There are two known types of ER, $\alpha$ and $\beta$ (16). From these ER, splice variants have been identified that are tissue-specific expressed $(17,18)$. The proteins encoded by these isoforms are believed to be important modulators of the tissue- and promoter-specific effects of estradiol.

The purpose of the first experiment in this study was to investigate whether a combination of the established $\mathrm{GnRH}$ agonist triptorelin along with the GnRH antagonist cetrorelix acetate is more effective in suppressing gonadotropin levels than the established GnRH agonist treatment or the nonestablished GnRH antagonist treatment, and to look for the effects on hypothalamic and pituitary expression of several genes that are involved in the regulation of sexual maturation. In the first experiment, ovariectomized rats were used as this model is suitable for studying gonadotropin suppressant effects of $\mathrm{GnRH}$ analogues. The explanted ovaries were investigated to verify direct ovarian gonadotropin-independent effects of both $\mathrm{GnRH}$ analogues that we found in recent studies when we analyzed puberty-inhibiting effects of GnRH analogues in normal peribubertal rats $(14,19)$ and demonstrated their influence on ovarian GnRH receptor expression. Because these same studies indicated that the GnRH antagonist cetrorelix has advantages both in speed and directness when controlling precocious puberty, in the second experiment of this study we tested the effects of a new long-acting depot preparation of the $\mathrm{GnRH}$ antagonist cetrorelix, cetrorelix embonate, using a female rat model of androgen-induced precocious puberty and investigated the gene expression of GnRH and its receptor as well as different estrogen receptors at the hypothalamic, pituitary, ovarian, and uterine levels.

\section{MATERIAL AND METHODS}

Animals and drugs. This study was approved by the local ethical committee for animal experiments (No. 509.42502/013.00). Female Sprague-Dawley rats were housed under standardized conditions (lights on from $0700 \mathrm{~h}$ to $1900 \mathrm{~h}, 25^{\circ} \mathrm{C}$ room temperature, free access to water and fed ad libitum).

In Experiment 1, animals were randomized into four groups, each consisting of 10-11 animals. Each animal was marked with a code on the tail for identification purposes. On postnatal d 29, all rats were ovariectomized under ether anesthesia. Two days later, rats were treated intraperitoneally with single daily
$0.4 \mathrm{~mL}$ injections of either 1) $\mathrm{GnRH}$ antagonist cetrorelix and on d 3 of treatment, a combination of cetrorelix plus $\mathrm{GnRH}$ agonist triptorelin (Group CT3, C $30 \mu \mathrm{g} / \mathrm{d} 5 \mathrm{~d}$, combination with $\mathrm{T} 30 \mu \mathrm{g} / \mathrm{d}$ for $3 \mathrm{~d}$ ); 2) cetrorelix in combination with triptorelin (group CT5: each drug $30 \mu \mathrm{g} / \mathrm{d}, 5 \mathrm{~d}$ ); 3) triptorelin (group T5, $30 \mu \mathrm{g} / \mathrm{d}, 5 \mathrm{~d}$ ); or 4) saline (control group $\mathrm{Co}, \mathrm{NaCl}$ $0.9 \%$ ). Figure 1 provides a schematic overview of Experiment 1 injections. Cetrorelix acetate used in this experiment was provided as a nondepot preparation by Asta Medica, Frankfurt/ Main, Germany, dissolvable in distilled water. Triptorelin was purchased from Bachem, Bubendorf, Switzerland. Blood samples were taken from the tail vein after the second injection and from the trunk after decapitation $5 \mathrm{~h}$ after the fifth (final) injection. Brains and pituitaries were rapidly collected and immediately frozen on ice. Tissues were stored at $-70^{\circ} \mathrm{C}$ until analysis. Hypothalamic and pituitary mRNA levels for $\mathrm{GnRH}$, GnRH receptor, $\mathrm{ER} \alpha$ and $\beta$, and gonadotropin subunit $\mathrm{LH} \beta$ were measured by quantitative TaqMan PCR.

To investigate potential direct ovarian effects of $\mathrm{GnRH}$ analogues, explanted ovaries were incubated with GnRH analogues in vitro. The bursa of explanted ovaries was rapidly removed and ovaries were randomized and incubated in Dulbecco minimal medium, $10 \mathrm{mM}$ HEPES buffer, $95 \% \mathrm{O}_{2} /$ $5 \% \mathrm{CO}_{2}, 37^{\circ} \mathrm{C}$, with cetrorelix $10^{-6} \mathrm{M}$, triptorelin $10^{-6} \mathrm{M}$, or $\mathrm{NaCl} 0.9 \%$; each group consisted of 12-14 ovaries. Medium was changed every $30 \mathrm{~min}$. After $4 \mathrm{~h}$ incubation, ovaries were frozen in liquid nitrogen for $\mathrm{GnRH}$ and $\mathrm{GnRH}$ receptor mRNA analysis by TaqMan PCR.

In Experiment 2, 5-d-old female rats were randomized into two groups. They were treated with either a single s.c. injection of $300 \mu \mathrm{g}$ danazol in $0.2 \mathrm{~mL}$ saline (18 animals - group Dan) to induce precocious puberty, or a single s.c. injection of 0.2 $\mathrm{mL}$ saline (11 animals - controls, group Co), according to a method published by Morishita et al. (20). They were weighed and monitored daily for vaginal opening marking the beginning of puberty. At d 26, the 18 danazol-treated rats were randomized further into two groups ( 9 animals each). Rats were treated intraperitoneally with a single $0.4 \mathrm{~mL}$ injection of either 300

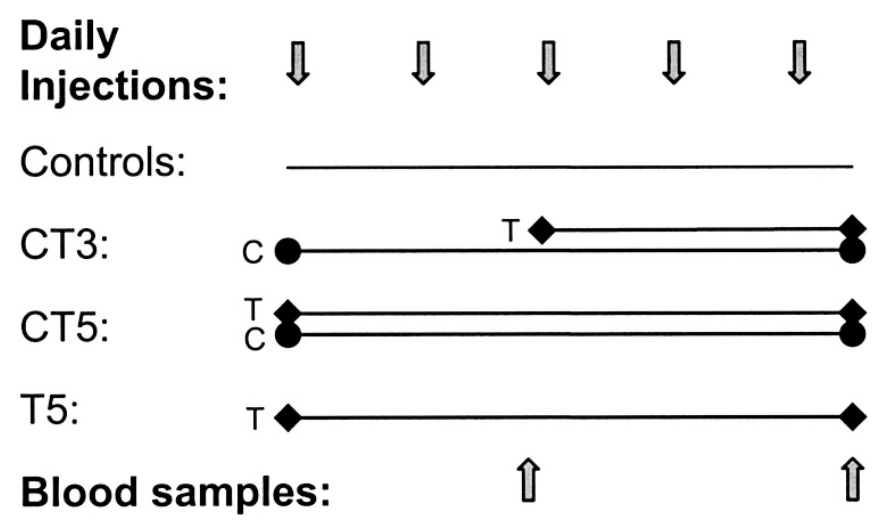

Figure 1. Experiment 1, ovariectomized rats, triptorelin alone and in combination with cetrorelix: schematic overview of treatment method, schedule, and groups. Daily injection - 5-d treatment initiated postnatal d 31. Controls = saline treatment; CT3 = cetrorelix for $2 \mathrm{~d}$ followed by combination treatment (cetrorelix + triptorelin) commencing treatment d 3; CT5 = combination treatment entire $5 \mathrm{~d}$; T5 = triptorelin treatment only. Blood samples taken $24 \mathrm{~h}$ after the second and $5 \mathrm{~h}$ after the fifth injection. 
$\mu \mathrm{g}$ cetrorelix depot (cetrorelix embonate-group DanCet) or saline (untreated controls Co and group Dan). Three days later, the rats were decapitated and blood was collected from the trunk. Brains, anterior pituitaries, ovaries, and uteri were rapidly removed and frozen on dry ice for later mRNA studies with real-time reverse transcription (RT)-PCR.

Serum hormones. Serum levels of LH, FSH, and estradiol were determined using established RIA-methods. Estradiol was measured using a sensitive commercial RIA (Diagnostic Systems Laboratories, Webster, TX, U.S.A.) with a lower detection limit of $1.2 \mathrm{pg} / \mathrm{mL}$. Reference preparations were RP2 for both LH and FSH. For iodination, LH I-6 and FSH I-7 were used. To achieve maximum sensitivity, $100 \mu \mathrm{L}$ serum was used for LH and FSH measurements. Each assay was performed with freshly prepared tracer, which had been purified by FPLC-column chromatography on Superdex 75 column (Amersham Pharmacia Biotech, Freiburg, Germany). The antibodies were NIADDK rat-S7 (LH) and NIADDK rat-S11 (FSH). The sensitivity limits were $0.05 \mathrm{ng} / \mathrm{mL}$ (LH) and 0.4 $\mathrm{ng} / \mathrm{mL}$ (FSH). The intra- and interassay coefficients of variation from replicates of pooled samples from ovariectomized rats were $7.5 \%$ and $11.5 \%(\mathrm{LH})$, and $8.5 \%$ and $13.5 \%(\mathrm{FSH})$.

RNA preparation and real-time RT-PCR. RNA isolation from the anterior pituitary, micropunches of the POA, and tissues of the MBH, ovary, and uterus of each animal was carried out with the Rneasy Total RNA Kit (QIAGEN GmbH, Hilden, Germany) as described in detail in our recent study (19). Depending on the tissue, $10-50 \mathrm{ng} \mathrm{RNA} / \mu \mathrm{L}$ was used for the RT. The RT reaction proceeded at $22^{\circ} \mathrm{C}$ for $10 \mathrm{~min}$ and $42^{\circ} \mathrm{C}$ for $50 \mathrm{~min}$, with $15 \mathrm{ng}$ (GnRH POA) to $250 \mathrm{ng}(\mathrm{GnRH}$ receptor uterus) total RNA. The reaction mixture contained 5 $\mathrm{ng} / \mu \mathrm{L}$ random primers, $1 \times$ reaction buffer, $10 \mathrm{mM}$ DTT, 500 nM deoxy-NTPs, 200 U Superscript reverse transcriptase (all reagents from Invitrogen, Carlsbad, CA, U.S.A.) and $10 \mathrm{U}$ ribonuclease inhibitor (Promega, Mannheim, Germany) in a final volume of $20 \mu \mathrm{L}$. At the end of incubation, the samples were heated at $95^{\circ} \mathrm{C}$ for $10 \mathrm{~min}$ to inactivate the enzyme and denature RNA-cDNA hybrids. The mRNA levels were quantified using TaqMan real-time RT-PCR as described in detail in our recent study (19). Gene-specific PCR primer pairs and the hybridization probes were designed using the Primer Express software (Applied Biosystems, Foster City, CA, U.S.A.). The sequences according to different genes and the GenBank accession numbers are shown in Table 1. Each PCR run included 7 points of the standard curve, a no template control, and the sample cDNA. Amplification reactions $(25 \mu \mathrm{L})$ contained 12.5 $\mu \mathrm{L}$ TaqMan buffer (PerkinElmer Life Sciences, Boston, MA, U.S.A.), 300-900 $\mathrm{nM}$ of each primer, $225 \mathrm{nM}$ hybridization probe, and $4 \mu \mathrm{L}$ cDNA. Each PCR product was cloned into the pCR II-TOPO plasmid following the manufacturer's instructions (Invitrogen) to generate cRNA for standard curves.

Statistical evaluation and mathematical calculations. Unless otherwise stated, results are presented as mean \pm SEM. As normal distributions could not be assumed, all data from the RIA and PCR analysis were statistically evaluated with the Kruskal-Wallis test followed by Dunn's test to compare multiple groups. Differences were considered significant if $p<$ 0.05 . The analysis was performed by using the Prism program (GraphPad Software, San Diego, CA, U.S.A.).

\section{RESULTS}

Experiment 1, ovariectomized rats, triptorelin alone and in combination with cetrorelix. The lowest LH and FSH levels in Experiment 1 were measured in group CT3 after two injections of cetrorelix-only treatment, single injection per day (before treatment on d 3 with a combination of cetrorelix plus $\mathrm{GnRH}$ agonist triptorelin). LH and FSH levels at the same time point were also significantly reduced in group CT5 (cetrorelix combined with triptorelin from d 1), but not in group T5 (triptorelin treatment alone). Table 2 provides an overview of treatment group comparisons. After injection on the fifth treatment day (single injection per day), LH and FSH levels were significantly reduced in both combined-treatment groups, CT3 and CT5, but compared with precombined treatment values before d 3 in group CT3, there was a significant increase of LH and FSH in group CT3 after combining cetrorelix with triptorelin (Table 2).

GnRH expression was investigated in the POA of the hypothalamus, where GnRH neurons are located. There were no

Table 1. Sequences of forward (f) and reverse (r) primers and TaqMan hybridization probes

\begin{tabular}{|c|c|c|}
\hline Probe & Sequence & GenBank Accession \\
\hline \multirow[t]{3}{*}{ GnRH } & f 5'-GCAGAACCCCAGAACTTCGA-3' & NM_012767 \\
\hline & r 5'-TGCCCAGCTTCCTCTTCAAT-3' & \\
\hline & TaqMan: 5'FAM-TCTGCGAGGAGCTCTGGAACGTCTG-TAMRA3' & \\
\hline \multirow{2}{*}{ GnRH receptor } & r $5^{\prime}$-TCTCGCAATGTGTGACCCAC- $3^{\prime}$ & \\
\hline & TaqMan: 5'FAM-TTCATGCCACCATTGCGGAAAGCTG-TAMRA3' & \\
\hline $\mathrm{LH} \beta$ & f $5^{\prime}$-ACCTTCACCACCAGCATCTGT-3' & NM_012858 \\
\hline \multirow[t]{3}{*}{$\mathrm{ER} \alpha$} & f $5^{\prime}$-AAGCTGGCCTGACTCTGCAG-3' & X61098 \\
\hline & r 5'-GCAGGTCATAGAGAGGCACGA-3' & \\
\hline & TaqMan: 5'FAM-CGTCTGGCCCAGCTCCTCCTCATC-TAMRA3' & \\
\hline \multirow[t]{3}{*}{$\mathrm{ER} \beta$} & f $5^{\prime}$-GAGGAGATACCACTCTTCGCAATC-3' & U57439 \\
\hline & r 5'-GGAGTATCTCTGTGTGAAGGCCAT-3' & \\
\hline & TaqMan: 5'FAM-CAGGGCATCTGTCACCGCGTTCAG-TAMRA3' & \\
\hline
\end{tabular}

For references, see NCBI GenBank accession numbers. 
Table 2. Experiment 1, serum LH and FSH levels in ovariectomized rats after daily injections of cetrorelix (C) and/or triptorelin (T)

\begin{tabular}{|c|c|c|c|c|c|c|c|c|c|}
\hline \multirow{2}{*}{$\frac{\text { Groups }}{\text { Controls }}$} & \multirow{2}{*}{$\begin{array}{c}\text { No. } \\
11\end{array}$} & \multicolumn{4}{|c|}{ LH } & \multicolumn{4}{|c|}{ FSH } \\
\hline & & 3.16 & 0.55 & 4.88 & 1.07 & 44.2 & 5.0 & 49.3 & 3.8 \\
\hline CT3 & 10 & 0.08 & $0.02^{\mathrm{a}, \mathrm{c}}$ & 2.72 & $1.79^{\mathrm{d}}$ & 10.8 & $2.8^{\mathrm{a}, \mathrm{d}}$ & 25.4 & $1.6^{\mathrm{b}}$ \\
\hline
\end{tabular}

Blood samples were taken $24 \mathrm{~h}$ after the 2 nd injection and $5 \mathrm{~h}$ after the 5 th (final) injection.

${ }^{\mathrm{a}} p<0.001$ vs controls (same time point).

${ }^{\mathrm{b}} p<0.01$ vs controls (same time point).

${ }^{\mathrm{c}} p<0.001$ vs $\mathrm{T} 5$ (same time point).

${ }^{\mathrm{d}} p<0.01$ vs T5 (same time point).

significant differences between the treatment groups (data are not shown).

GnRH receptor mRNA levels were measured in the POA, the $\mathrm{MBH}$, and the pituitary. The hypothalamic expression (POA, MBH) was comparable in all groups (data not shown), whereas the pituitary $\mathrm{GnRH}$ receptor was up-regulated in group T5 (Fig. 2a).

Pituitary expression of the gonadotropin subunit $\mathrm{LH} \beta$ was significantly reduced in groups CT3 and CT5 (Fig. $2 b$ ).

$\mathrm{ER} \alpha$ and $\mathrm{ER} \beta$ mRNA levels were determined in the pituitary. ER $\alpha$ levels were comparable in all groups, but ER $\beta$ levels were significantly stimulated in group CT3 (Fig. 2c).

In explanted ovaries, GnRH expression was detectable but there were no significant differences among the treatment groups (data not shown). GnRH receptor expression was significantly reduced after incubation with cetrorelix but not by triptorelin (Fig. 3).

Experiment 2, danazol-induced precocious puberty, cetrorelix depot. At age of 23-26 d, vaginal opening occurred in all but two danazol treated rats, which occurred in our colony 32-37 d in the majority of untreated rats, indicating onset of puberty (19). After treatment with cetrorelix depot (group DanCet) or saline (groups Co and Dan), the weight gain and body weights at $\mathrm{d} 29$ were similar in all three groups (data not shown). None of the control animals showed pubertal signs on d 29. At time of decapitation, serum estradiol levels in danazoltreated rats (group Dan) were higher compared with controls, but lower in group DanCet animals treated with a single injection of cetrorelix depot (Fig. 4).

GnRH expression was determined in the POA. The groups Dan and DanCet had slightly but not significantly lower GnRH expression in the POA (Fig. 5a). Ovarian GnRH expression was slightly reduced in group DanCet (data not shown) and uterine GnRH mRNA levels were lower in groups Dan and DanCet (Fig. 5b).

After treatment with cetrorelix in danazol-pretreated rats (group DanCet), the GnRH receptor expression was stimulated in the hypothalamus (Fig. 6a) but down-regulated in the pituitary and ovary (Fig. 6, $b$ and $c$ ). There were no detectable differences between the groups in the uterus (data not shown).

Pituitary gonadotropin subunit $\mathrm{LH} \beta$ expression was significantly reduced in group DanCet (Fig. 7).
ER $\alpha$ mRNA levels, determined in the pituitary, ovary, and uterus, and pituitary ER $\beta$ mRNA levels did not show significant changes among the groups (data not shown). ER $\beta$ mRNA levels were inhibited by cetrorelix in the ovary and uterus (Fig. $8, a$ and $b$ ).

\section{DISCUSSION}

In the first part of our study we used ovariectomized rats to test whether a combination of the established GnRH agonist triptorelin with a short-acting GnRH antagonist cetrorelix acetate is more effective and faster in suppressing gonadotropin levels. The results demonstrate that the combination treatment of $\mathrm{GnRH}$ analogues is indeed more effective but the antagonist alone most profoundly suppresses gonadotropin levels. This means that the flare-up of gonadotropin secretion associated with conventional agonist treatment can be avoided by using either a combined analogue or antagonist alone treatment. Furthermore, we could show direct ovarian effects of cetrorelix on GnRH receptor expression in vitro, implying that the local GnRH autoregulatory system of the ovary can be influenced by GnRH antagonists. These peripheral effects have to be considered when deciding which GnRH analogue is most suitable for treating precocious puberty. In the second part of our study we demonstrated for the first time the puberty-arresting effects of a long-acting GnRH antagonist, cetrorelix embonate, in a rat model of androgen-induced precocious puberty using a single danazol injection in neonatal rats. At age of 23-26 d, pubertal signs occurred in the majority of danazol treated rats, confirming the model first described by Morishita et al. (20) who found true precocious puberty with elevated LH levels and advanced onset of estrous cyclicity in danazol-treated female rats.

To compare the effects of agonistic with antagonistic GnRH analogues on gonadotropin secretion, in the first experiment we used ovariectomized prepubertal female rats rather than intact rats because LH and FSH levels in intact rats are very low at the prepubertal age. As the signal transduction differs between agonistic and antagonistic GnRH analogues, we studied the effectiveness of a combination of the GnRH agonist triptorelin with the GnRH antagonist cetrorelix acetate in suppressing gonadotropin secretion. From a recent study with intact peripubertal female rats, we know that during 12-d treatment with 
a
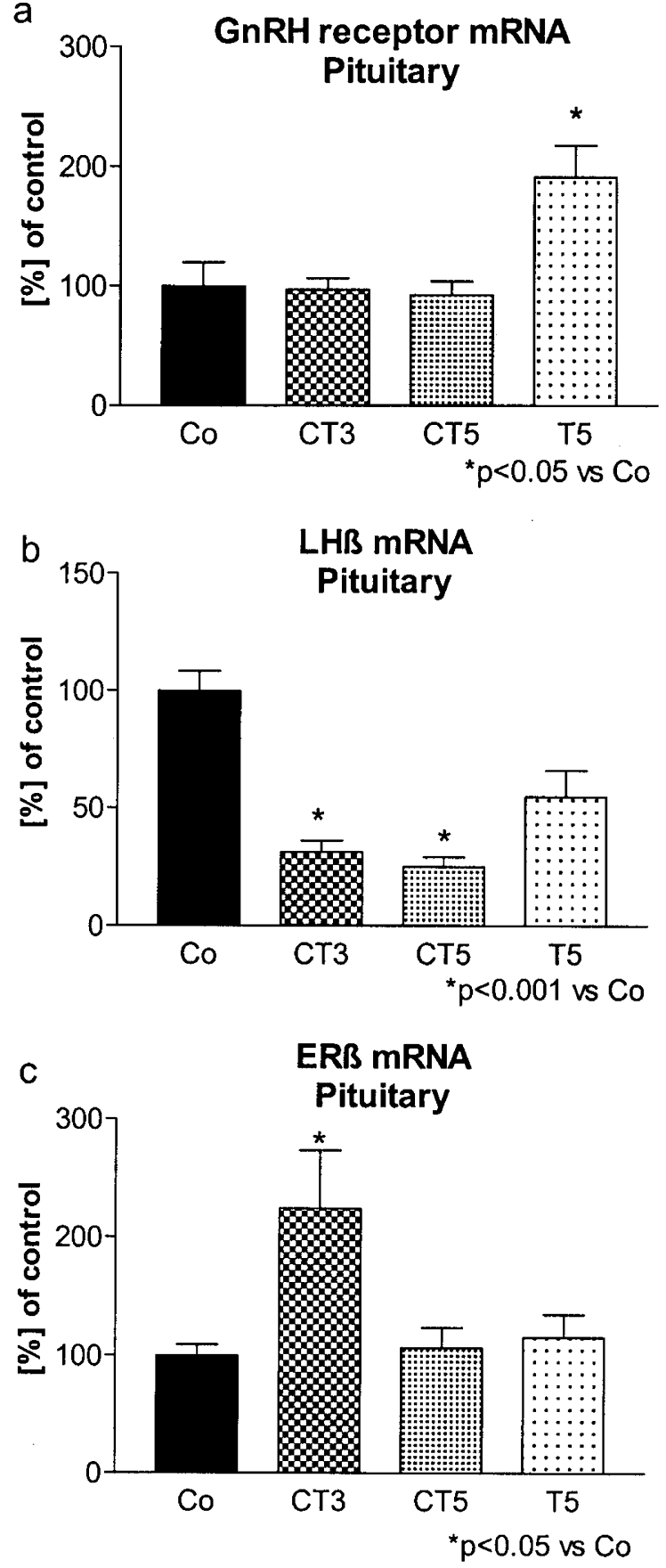

Figure 2. Experiment 1, ovariectomized rats, triptorelin alone and in combination with cetrorelix: pituitary expression for GnRH receptor, LH $\beta$, and $\mathrm{ER} \beta$. (a) GnRH receptor mRNA stimulated after triptorelin only treatment (group T5); (b) gonadotropin subunit $\mathrm{LH} \beta$ mRNA significantly reduced in antagonist/agonist combination groups (CT3 and CT5); and (c) ER $\beta$ mRNA levels significantly stimulated in delayed combination group (CT3).

daily triptorelin injections, serum gonadotropins are stimulated; whereas after the first injection with cetrorelix, serum gonadotropins are suppressed and are never stimulated throughout treatment (14). In the present study with ovariectomized rats, gonadotropins dramatically dropped after two injections of cetrorelix (Group CT3) or cetrorelix combined with triptorelin (Group CT5), whereas during triptorelin treatment, gonadotropin levels were stimulated. Pituitary gonado-

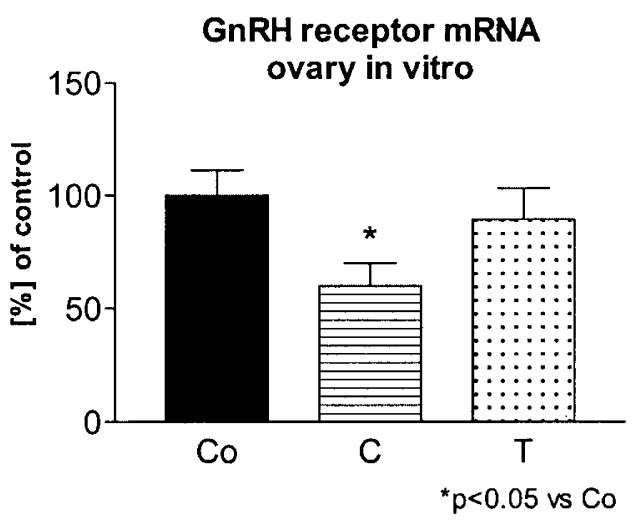

Figure 3. Experiment 1, ovariectomized rats: GnRH receptor mRNA ovary in vitro. Ovarian GnRH receptor mRNA levels after $4 \mathrm{~h}$ in vitro incubation significantly reduced by antagonist cetrorelix $10^{-6} \mathrm{M}$ (group C) but not by agonist triptorelin $10^{-6} \mathrm{M}$ (group $\mathrm{T}$ ) compared with controls (Co).

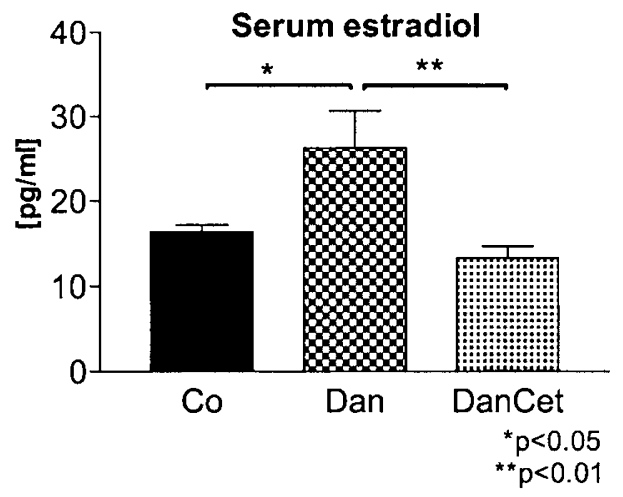

Figure 4. Experiment 2, danazol-induced precocious puberty, cetrorelix depot: serum estradiol levels. Serum estradiol levels in danazol-treated rats (group Dan) were higher compared with controls, but lower when animals were treated with a single injection of depot GnRH antagonist cetrorelix embonate (group DanCet).

tropin subunit $\mathrm{LH} \beta$ expression was inhibited by cetrorelix with or without combination with triptorelin, but no significant changes were detected by triptorelin alone. This finding reinforces the fast and direct gonadotropin-suppressant effects of the GnRH antagonist.

GnRH mRNA levels, analyzed in the POA where the perikarya of GnRH neurons are located, showed high variations and were unchanged after treatment with $\mathrm{GnRH}$ analogues or precocious puberty-enducing danazol. These results are similar to those of our previous studies, where no changes of GnRH expression in the POA were found in the transition from prepubertal to pubertal rats (21), nor after treatment of peripubertal female rats with agonistic and antagonistic GnRH analogues (19). But it is yet unknown what amounts of GnRH analogues pass the blood-brain barrier and reach the GnRH perikarya and axon terminals.

In the second experiment of this study, GnRH mRNA levels could also be measured in the ovary and uterus. This is an important finding. GnRH agonists have been found to directly inhibit rat uterine cells (22). In our danazol precocious puberty-induced rats, uterine mRNA levels remained low, independent of GnRH antagonist treatment. To further investigate this phenomenon, it will be necessary to measure mRNA levels at different time points. 
a

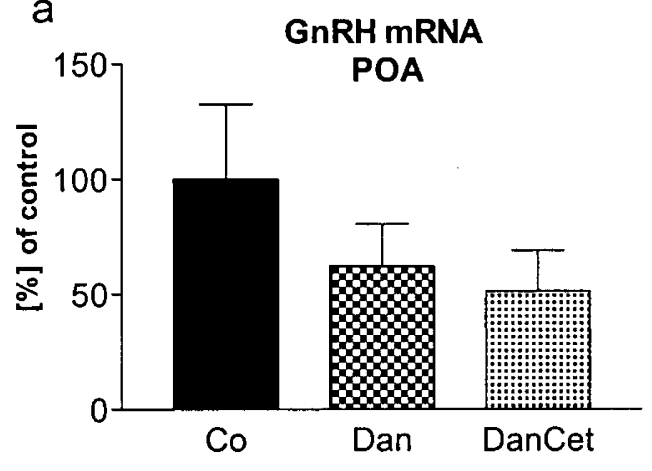

b

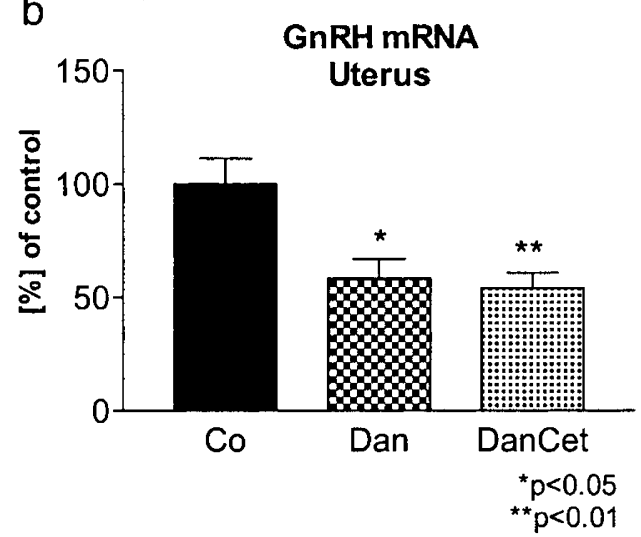

Figure 5. Experiment 2, danazol-induced precocious puberty, cetrorelix depot: GnRH expression. (a) GnRH mRNA levels in POA of groups Dan and DanCet slightly but not significantly lower compared with controls; (b) GnRH mRNA levels in uterus significantly reduced in groups Dan and DanCet compared with controls.

The GnRH receptor itself is subject to regulation by $\mathrm{GnRH}$ (23-25). Pulsatile stimulation or low doses of GnRH upregulate its receptor, whereas high doses, continuous treatment, or no exposure down-regulate the GnRH receptor in the pituitary. The number of GnRH receptors correlates with the sensitivity of the pituitary to GnRH (26). Estradiol is known as a positive regulator of $\mathrm{GnRH}$ receptor gene expression in the preovulatory period. An increased serum concentration of estradiol most likely causes elevation of pituitary GnRH receptor mRNA, which precedes maximal numbers of $\mathrm{GnRH}$ receptors before the LH surge. Through this mechanism, maximal sensitivity of gonadotrophs to GnRH is achieved, indicating that both GnRH and ovarian factors control the synthesis and secretion of the gonadotropins $(27,28)$. In the first experiment of our study, the up-regulated GnRH receptor by triptorelin 30 $\mu \mathrm{g} / \mathrm{d}$ is in line with our previous study, where GnRH receptor mRNA levels were up-regulated by low-dose triptorelin (10 $\mu \mathrm{g} / \mathrm{d})$ but not by high-dose triptorelin $(100 \mu \mathrm{g} / \mathrm{d})(19)$. In the combination treatment of triptorelin with cetrorelix of the present study, no changes of pituitary GnRH receptor mRNA levels could by observed. This could be due to the lack of estrogen in ovariectomized rats or caused by opposing, i.e. stimulating and inhibiting, effects of both analogues that counteract each other's effect. After treatment of intact animals with depot-antagonist cetrorelix embonate, low pituitary GnRH re-
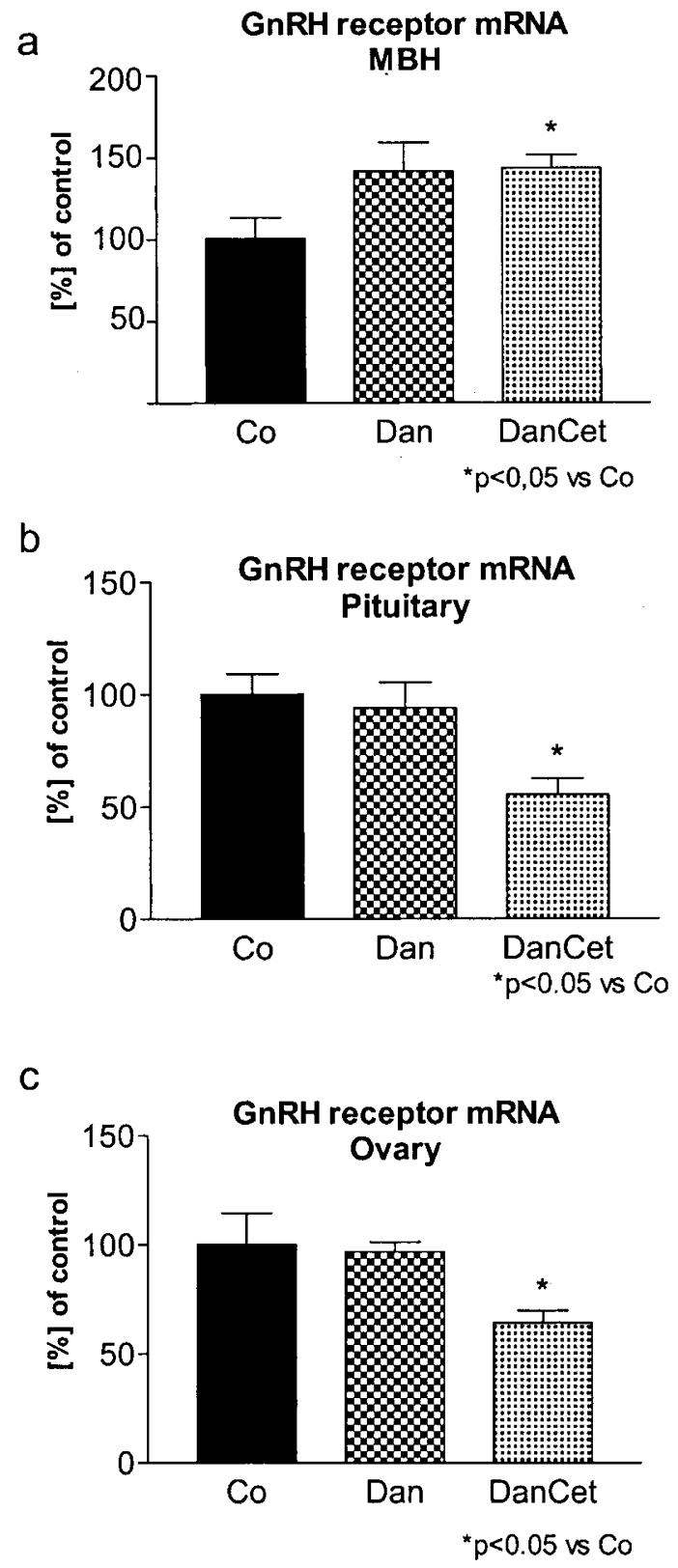

Figure 6. Experiment 2, danazol-induced precocious puberty, cetrorelix depot: GnRH receptor expression. (a) GnRH receptor mRNA levels stimulated in $\mathrm{MBH}$, but $(b)$ inhibited in pituitary and (c) ovary after treatment with cetrorelix embonate (group DanCet) compared with controls.

ceptor mRNA levels indicate a down-regulation of $\mathrm{GnRH}$ receptors. Furthermore, ovarian GnRH receptor mRNA levels were inhibited by cetrorelix in vivo as well as in vitro. This means that, at least in the absence of pituitary hormones, GnRH antagonists exert direct ovarian actions. Furthermore, GnRH receptor expression was clearly detectable in both the $\mathrm{MBH}$ and uterus.

Two discrete nuclear ER have been identified: the classic $\mathrm{ER} \alpha$, and the recently cloned $\mathrm{ER} \beta$. In our experiments, there were no significant changes of ER $\alpha$ expression in different tissues among the treatment groups. In Experiment 1, pituitary $\mathrm{ER} \beta$ was stimulated in group CT3, cetrorelix alone followed by cetrorelix in combination with triptorelin, indicating that 


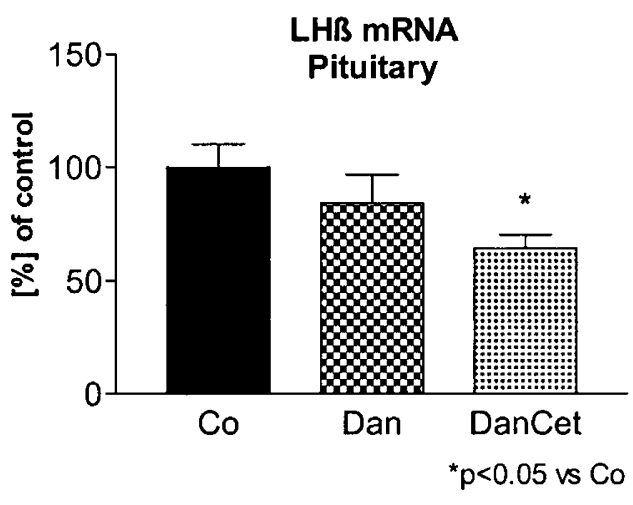

Figure 7. Experiment 2, danazol-induced precocious puberty, cetrorelix depot: $\mathrm{LH} \beta$ expression. Gonadotropin subunit $\mathrm{LH} \beta$ mRNA levels in pituitary significantly reduced after treatment with cetrorelix embonate (group DanCet) compared with groups Dan and controls.

a

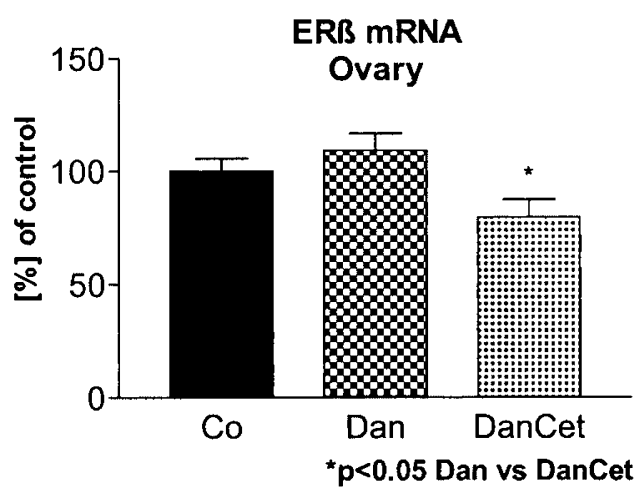

b

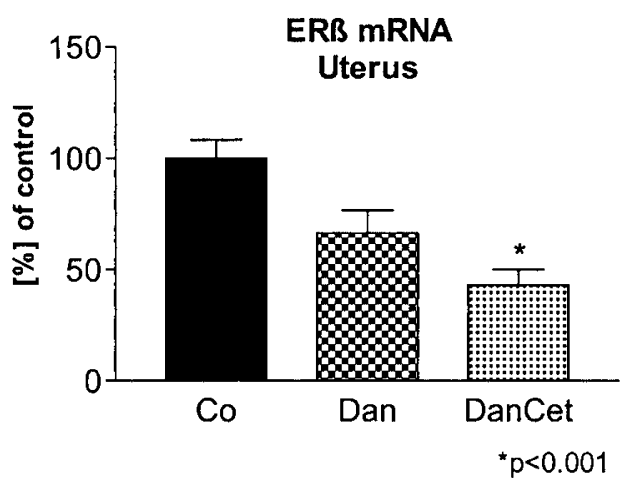

Figure 8. Experiment 2, danazol-induced precocious puberty, cetrorelix depot: ER $\beta$ expression. (a) ER $\beta$ mRNA levels in ovary inhibited by antagonist (group DanCet) compared with group Dan and controls; (b) ER $\beta$ mRNA levels in uterus significantly inhibited by antagonist (group DanCet) compared with controls.

this sequential combination activates other mechanisms than a combined treatment administered from the beginning. In danazol-induced precocious puberty rats, the lower ovarian and uterine $\mathrm{ER} \beta$ expression in cetrorelix-treated rats is in line with suppressed estrogen levels in these animals.

Antagonistic GnRH analogues potentially offer a faster, direct, and dose-dependent alternative for treating central precocious puberty compared with agonists without initial activa- tion of the gonadotropin secretion known as the "flare-up" effect. In contrast to the mandatory chronic administration of the GnRH agonists, it has been demonstrated that it is possible to titrate the gonadotropin suppressive effect using only one injection of a GnRH antagonist (29). In danazol-induced puberty, we chose a 3-d interval to investigate the effects of cetrorelix depot. Further experiments are needed for pharmacokinetic studies. Other long-acting $\mathrm{GnRH}$ antagonists such as degarelix (30) and newly developed oral nonpeptide $\mathrm{GnRH}$ antagonists that have been tested in rats, dogs and monkeys, are potential drugs for puberty studies $(31,32)$.

We conclude that these data imply profound potential for quick, direct, and more manageable treatment of precocious puberty with $\mathrm{GnRH}$ antagonists rather than agonists. Compared with $\mathrm{GnRH}$ antagonist-treatment alone, combinationtreatments of $\mathrm{GnRH}$ antagonistic with agonistic analogues have no advantageous effects in suppressing gonadotropin levels. But when long-acting depot preparations are only available as agonists, the combination of a short-acting antagonist with a long-acting agonist could prevent the gonadotropin "flare-up" at the beginning of agonist treatment. We should also note that we found Morishita's female rat model of androgen-induced precocious puberty suitable to study the effects of puberty-inhibiting drugs and recommend it for further such studies.

Acknowledgments. The authors thank Dr. Reissmann, Asta Medica, who kindly provided the drug cetrorelix acetate and long-acting cetrorelix embonate to us as a gift. The authors also thank M. Neff-Heinrich for linguistic help in editing the manuscript and M. Metten for her assistance in the laboratory.

\section{REFERENCES}

1. Urbanski HF, Ojeda SR 1990 A role for $N$-methyl-D-aspartate (NMDA) receptors in the control of LH secretion and initiation of female puberty. Endocrinology 126:1774-1776

2. Moguilevsky JA, Carbone S, Szwarcfarb B, Rondina D 1991 Sexual maturation modifies the GABAergic control of gonadotrophin secretion in female rats. Brain Res $563: 12-16$

3. Bourguignon JP, Gérard A, Alvarez Gonzalez ML, Franchimont P 1992 Neuroendocrine mechanisms of onset of puberty. J Clin Invest 90:1736-1744

4. Rage F, Hill DF, Sena-Esteves M, Breakefield XO, Coffey RJ, Costa ME, McCann SM, Ojeda SR 1997 Targeting transforming growth factor alpha expression to discrete loci of the neuroendocrine brain induces female sexual precocity. Proc Natl Acad Sci U S A 94:2735-2740

5. Aubert ML, Pierroz DD, Gruaz NM, d‘Alleves V, Vuagnat BA, Pralong FP, Blum WF, Sizonenko PC 1998 Metabolic control of sexual function and growth: role of neuropeptide Y and leptin. Mol Cell Endocrinol 140:107-113

6. Lebrethon MC, Vandersmissen E, Gerard A, Parent AS, Junien JL, Bourguignon JP 2000 In vitro stimulation of the prepubertal rat gonadotropin-releasing hormone pulse generator by leptin and neuropeptide Y through distinct mechanisms. Endocrinology 141:1464-1469

7. Crowley Jr WF, Comite F, Vale W, Rivier J, Loriaux DL, Cutler Jr GB 1981 Therapeutic use of pituitary desensitization with a long-acting LHRH agonist: a potential new treatment for idiopathic precocious puberty. J Clin Endocrinol Metab 52:370-372

8. Redding TW, Schally AV, Tice TR, Meyers WE 1984 Long-acting delivery systems for peptides: inhibition of rat prostate tumors by controlled release of [D-Trp6] luteinizing hormone-releasing hormone from injectable microcapsules. Proc Natl Acad Sci U S A 81:5845-5848

9. Plosker GL, Brogden RN 1994 Leuprorelin - a review of its pharmacology and therapeutic use in prostatic cancer, endometriosis and other sex hormone-related disorders. Drugs 48:930-967

10. Oostdijk W, Rikken B, Schreuder S, Otten B, Odink R, Rouwe C, Jansen M, Gerver WJ, Waelkens J, Drop S 1996 Final height in central precocious puberty after long term treatment with a slow release GnRH agonist. Arch Dis Child 75:292-297

11. Heger S, Partsch CJ, Sippell WG 1999 Long-term outcome after depot gonadotropinreleasing hormone agonist treatment of central precocious puberty: final height, body 
proportions, body composition, bone mineral density, and reproductive function. J Clin Endocrinol Metab 84:4583-4590

12. Partsch CJ, Heger S, Sippell WG 2002 Management and outcome of central precocious puberty. Clin Endocrinol (Oxf) 56:129-148

13. Beckers T, Marheineke K, Reiländer H, Hilgard P 1995 Selection and characterization of mammalian cell lines with stable over-expression of human pituitary receptors for gonadoliberin. Eur J Biochem 231:535-543

14. Roth C, Leonhardt S, Seidel C, Luft H, Wuttke W, Jarry H 2000 Comparative analysis of different puberty inhibiting mechanisms of two GnRH agonists and the GnRH antagonist cetrorelix using a female rat model. Pediatr Res 48:468-474

15. Friend KE, Ang LW, Shupnik MA 1995 Estrogen regulates the expression of several different estrogen receptor mRNA isoforms in rat pituitary. Proc Natl Acad Sci U S A 92:4367-4371

16. Gustafsson JA 1999 Estrogen receptor beta - a new dimension in estrogen mechanism of action. J Endocrinol 163:379-383

17. Kuiper GG, Carlsson B, Grandien K, Enmark E, Haggblad J, Nilsson S, Gustafsson JA 1997 Comparison of the ligand binding specificity and transcript tissue distribution of estrogen receptors $\alpha$ and $\beta$. Endocrinology 138:863-870

18. Schreihofer DA, Stoler MH, Shupnik MA 2000 Differential expression and regulation of estrogen receptors (ERs) in rat pituitary and cell lines: estrogen decreases ERalpha protein and estrogen responsiveness. Endocrinology 141:2174-2184

19. Roth C, Schricker M, Lakomek M, Strege A, Heiden I, Luft H, Munzel U, Wuttke W, Jarry H 2001 Autoregulation of the GnRH system during puberty: effects of antagonistic versus agonistic GnRH analogues in a female rat model. J Endocrinol 169:361-371

20. Morishita H, Takemoto M, Kondo H, Higuchi K, Aono T 1993 Induction of true precocious puberty by neonatal treatment with danazol in female rats. Neurosci Lett $157: 33-36$

21. Roth C, Leonhardt S, Theiling K, Lakomek M, Jarry H, Wuttke W 1998 Ontogeny of the GnRH-, glutaminase- and glutamate decarboxylase-gene expression in the hypothalamus of female rats. Brain Res Dev Brain Res 110:105-114

22. Sakamoto S, Tajima M, Sawaki K, Suzuki S, Kudo H, Sassa S, Kuwa K, Sugiura Y, Kasahara N, Nagasawa H 1993 Effects of luteinizing hormone-releasing hormone analogue on DNA synthesis in rat prostate and uterus. In Vivo 7:13-16
23. Haisenleder DJ, Cox ME, Parsons SJ, Marshall JC 1998 Gonadotropin-releasing hormone pulses are required to maintain activation of mitogen-activated protein kinase: role in stimulation of gonadotrope gene expression. Endocrinology 139:31043111

24. Loumaye E, Naor Z, Catt KJ 1982 Binding affinity and biological activity of gonadotropin releasing hormone agonists in isolated pituitary cells. Endocrinology 111:730-736

25. Tsutsumi M, Laws SC, Rodic V, Sealfon SC 1995 Translational regulation of the gonadotropin-releasing hormone receptor in alphaT3-1 cells. Endocrinology 136:1128-1136

26. Norwitz ER, Jeong KH, Chin WW 1999 Molecular mechanisms of gonadotropinreleasing hormone receptor gene regulation. J Soc Gynecol Investig 6:169178

27. Nett TM, Turzillo AM, Baratta M, Rispoli LA 2002 Pituitary effects of steroid hormones on secretion of follicle-stimulating hormone and luteinizing hormone. Domest Anim Endocrinol 23:33-42

28. Kang SK, Choi KC, Cheng KW, Nathwani PS, Auersperg N, Leung PC 2000 Role of gonadotropin-releasing hormone as an autocrine growth factor in human ovarian surface epithelium. Endocrinology 141:72-80

29. Behre HM, Kliesch S, Pühse G, Reissmann T, Nieschlag E 1997 High loading and low maintenance doses of a gonadotropin-releasing hormone antagonist effectively suppress serum luteinizing hormone, follicle-stimulating hormone, and testosterone in normal men. J Clin Endocrinol Metab 82:1403-1408

30. Broqua P, Riviere PJ, Conn PM, Rivier JE, Aubert ML, Junien JL 2002 Pharmacological profile of a new, potent, and long-acting gonadotropin-releasing hormone antagonist: degarelix. J Pharmacol Exp Ther 301:95-102

31. Ashton WT, Sisco RM, Kieczykowski GR, Yang YT, Yudkovitz JB, Cui J, Mount GR, Ren RN, Wu TJ, Shen X, Lyons KA, Mao AH, Carlin JR, Karanam BV, Vincent SH, Cheng K, Goulet MT 2001 Orally bioavailable, indole-based nonpeptide GnRH receptor antagonists with high potency and functional activity. Bioorg Med Chem Lett 11:2597-2602

32. Millar RP, Zhu YF, Chen C, Struthers RS 2000 Progress towards the development of non-peptide orally-active gonadotropin-releasing hormone $(\mathrm{GnRH})$ antagonists: therapeutic implications. Br Med Bull 56:761-772 